Pawee Romaniuk

University of Warmia and Mazury

in Olsztyn, Poland

\title{
TRADITIONS AND THE FUTURE OF SOCIAL CONSULTATIONS IN LOCAL GOVERNMENT UNITS
}

\begin{abstract}
This paper deals with public consultations, which are a form of direct democracy. The assumptions of such consultations were discussed from the theoretical and legal perspective. In the theoretical approach, an attempt was made to determine the direct democracy features and its relationship with the idea of local government, as well as understanding public consultations. Provisions of the local government law and by-laws were analysed from the legal perspective. Public consultations also have a wider context, which is determined by public participation and a new philosophy of government. Therefore, consultation involves not only consulting the public about a specific document, but also a comprehensive approach to cooperation with citizens.
\end{abstract}

KEYWORDs: public consultations, local government, participation, democracy, public administration 


\section{INTRODUCTION}

Public consultations with local government units guarantee that members of the local community can actively participate in managing public affairs. Recent observations show clearly that the process of public consultations has undergone considerable changes. The legislation provides significant freedom to local governments with respect to developing their own rules and procedures for holding public consultations.

Public consultations are one of the major forms of direct democracy. They play a key role in developing a democratic rule-of-law state while enabling the citizens to participate in managing public affairs. They can also be regarded as a communication system for public authorities with society. Public consultations have a unique form, especially in local governments, whose specificity lies in transferring powers to members of a local community and, in consequence, in cooperation in taking decisions. However, one must be aware that the effectiveness of their development in shaping the citizen society depends largely on the valid legal regulations. The main aim of this paper is to identify the changes in legal regulations applicable to public consultations in local government units. This analysis describes the methods applied in conducting the procedure, which undoubtedly affects the development of citizens' involvement in local public affairs.

\section{Principles OF CONSUltations}

It is an issue of key importance in public consultations to identify the circumstances in which they are justified, i.e. what is their basic object. One should note that the principle of public consultations is nothing other than submitting an issue for discussion or vote by members of a local community, such discussion or vote being part of the public consultations in question (E. Olejniczak-Szałowska, 1997, p. 103-119). Public consultations can be obligatory or optional (M. Banat, 2014, p. 13-14). Two types of obligatory consultations are identified in the literature. The first type has to be held under the relevant legislation. Consultations of the second type are made obligatory 
by the local government unit identified in the resolution on the rules and procedure of holding consultations (S. Grabowska, 2009, p. 253).

Apart from consultations that are obligatory under the common or local regulations, there are optional consultations. They are provided for in the local government acts and they can be held in matters essential to the commune, district or voivodship (the commune self-government act, the district self-government act, the voivodship self-government act). However, there is a dispute about whether "important matters" lie within the competence of a specific local government unit. It seems that they do not. Firstly, the legislation does not provide for such an obligation, as is the case, for example, with the local referendum. Secondly, legal regulations make it possible for public consultations to be held by local governments in matters outside their competence. This issue was dealt with by the Supreme Administrative Court (Decision of the Supreme Administrative Court of 17 December 1996-II SA / Kr 1766/96).

The repealed act on public consultations and referendum does not define clearly what should be meant by "important issues". Criteria appeared which specify clearly that a matter is of key importance for the development of the country, a specific area or citizens' interest and living conditions. However, in none of these cases are obligatory consultations provided for in this act. It seems justified that some changes should be introduced based on the valid legislation, which does not explain what categories of issues should be regarded as important and when public consultations should be held, given such a situation. It is particularly important that the criteria, based on which decisions are taken regarding the importance of a matter, should be defined precisely. Otherwise, the local government unit which initiates public consultations will have too much freedom in its decisions, which is the case at present (M. Mączyński, 2007, p. 92).

In such cases, $M$. Banat suggests adopting several criteria of the importance of matters:

- permanence, showing how permanent the changes in the functioning of the local government are made by the decisions taken in a longer perspective;

- amount of resources involved, i.e. what impact the decision will have on the local government unit budget; 
- the range of the decision impact, stating the number of the local community members affected by the decision consequences;

- nuisance, showing the extent to which a specific solution will adversely affect the quality of the local community life (M. Banat, 2014, p. 14).

\section{LEGAL AND ORGANISATIONAL BASIS OF PUBLIC CONSULTATIONS}

The possibility of holding public consultations among members of a local community is not directly provided for in the Constitution of the Republic of Poland (Constitution of the Republic of Poland of 2 April 1997). This does not mean that their foundations cannot be found in the constitution. This situation clearly refers to a democratic form of government, i.e. it involves taking decisions by a majority vote, which must be absolutely regulated by law. To determine this state of affairs, the doctrine refers many times to the concept of "participatory democracy", in which the mechanisms of the ruleof-law state and procedural democracy are joined with the local government to build elements of the common good (Article 1-2 of the Constitution of the Republic of Poland). This very important system of participation in local government should guarantee that all citizens have a right to decide on the ways of the state functioning, including local communities, as regards important matters on which they are required to express their opinion (D. Sześciło, 2012, p. 15-21).

However, Art. 4 of the Constitution of the Republic of Poland (Article 4 of the Constitution of the Republic of Poland) provides a characteristic point of reference to public consultations as a key process in the social dialogue and residents' participation in decision-making processes concerning local communities. Article 4 (1) of the constitution states directly that the supreme power in the Republic of Poland is vested in the Nation, and Article 4 (2) of the Constitution states that the Nation exercises such power directly or through their representatives, chosen in universal elections. The constitution also presents the standards of access to public information and information on the activities of public authorities. The Constitution of the Republic of 
Poland guarantees that every citizen is free to express their views and to acquire and disseminate information. Importantly, preventive censorship of the means of social communication and the licensing of the press is prohibited (Article 54 (1-2) of the Constitution of the Republic of Poland). Article 61 of the Constitution of the Republic of Poland is of great importance as the foundation for guaranteeing citizens' participation in public consultations. Under Article 61 (1) of the Constitution of the Republic of Poland, a citizen has the right to obtain information on the activities of organs of public authority as well as persons discharging public functions. Such a right also includes receipt of the information on the activities of self-governing economic or professional organs and other persons or organizational units relating to the field in which they perform the duties of public authorities and manage communal assets or property of the State Treasury (Article 61 (1) of the Constitution of the Republic of Poland). The right to obtain information ensures access to documents and entry to sittings of collective organs of public authority formed by universal elections, with the opportunity to make sound and visual recordings (Article 61 (1) of the Constitution of the Republic of Poland).

Obviously, as in each situation, this right may be limited. However, such limitations may be imposed only due to the protection of rights and liberties of other individuals and business entities as well as to the protection of public order, safety or an important economic interest of the state (P. Sitniewski, 2020, p. 161-187). Moreover, it should be noted that the Constitution of the Republic of Poland states that public authorities must pursue policies ensuring ecological security, that protection of the environment is the duty of public authorities and everyone has the right to be informed of the quality of the environment and its protection (Article 74 (1-3) of the Constitution of the Republic of Poland). It can be assumed that public consultations in local self-governing communities are held based on acts on local government. However, a detailed analysis of these acts shows that none of them contains a definition of public consultations, although Art. 5a of the act on commune self-government leaves no doubt as to the principles or the scope of public consultations (Article 5a (1-2) of the act on commune self-government). Article $5 \mathrm{a}$ (1) of the act states that, when provided for in the act or 
in other matters important for the commune, public consultations with its residents can be held. They are non-compulsory. Importantly, the rules and procedure of public consultations with the commune residents are specified in a resolution of the commune council.

It should also be noted that, under the act on commune self-government, public consultations may be obligatory or optional. The authorities are legally bound to seek the residents' opinion in situations specified in the act (K. Kozłowski, 2018, p. 36-40). Pursuant to the act on commune selfgovernment, public consultations have to be held if the Council of Ministers is to issue a regulation which establishes a commune or which makes changes in the area, which grants an urban charter and establishes the borders or which establishes the name of the commune and the seat of its authorities (Article 4 (1). Article $4 \mathrm{a}$ and Article $4 \mathrm{~b}$ of the act on commune self-government). Obligatory consultations with the residents are also held when an auxiliary entity is established by the council of the commune by way of a resolution (Article 5 (2) of the act on commune self-government). Interestingly, public consultations are obligatory under many other acts. For example, Article 5 (3-4) of the act on public benefit activities and voluntary service provides for an obligation:

- to consult NGOs about draft regulations concerning the statutory activities of such organisations;

- to hold consultations concerning the sphere of public tasks with public benefit activity councils, when they are established by competent local government units (Article 5 (2) (3 and 4) of the act on public benefit activities and voluntary service). Failure to hold such obligatory consultations often results in the invalidity of the legal action, for which such obligation is stipulated in the act, which may raise some constitutional doubts (Judgment of the Constitutional Tribunal of 27 November 2000-U 3/00, OTK 2000/8, item 293).

The district local government also has at its disposal the legal means for holding public consultations. Where it is provided for in the act, and in other matters important for the district, public consultations with the district residents may be held, with the rules and procedure of such consultations being laid down in a resolution of the district council (Article 3d (1-2) of the act 
on district self-government). In the case of the voivodship self-government, voivodship residents decide by universal vote (in elections and a referendum) or through voivodship self-government bodies (Article 5 (1) of the act on voivodship self-government). However, there is an analogy in the approach to the procedure and the method of holding public consultations, as such consultations can be held in the territory of a voivodship in situations specified in the act and in matters important for the voivodship. The rules and procedure of such consultations with the voivodship residents are laid down in a resolution of the voivodship sejmik (Article 10a (1-2) of the act on voivodship self-government).

\section{EVALUATION OF PUBLIC CONSULTATIONS}

Notably, the word "consultation" comes from Latin "consultatio", that is, "seeking counsel", as it usually means giving advice, seeking a specialist, expert opinion or specialist discussion of a matter. This refers to a typically expert nature of consultations and it is important to be able to express an opinion on a specific issue. When public consultations are held, the term is understood functionally, with reference to the process of expressing an opinion. When understood in this way, public consultations are regarded as seeking the opinion of third persons, who do not provide expert services but have their own opinions on the matter under consultation. It is because they are directly involved in the matter.

There is no precise scientific definition of public consultations. Based on scientific studies, this mechanism of public participation can be described as an intentional element of the decision-making process, in which the individuals concerned can participate. Under a general assumption, such individuals may represent a local community, acting in the community's best interest. However, according to G. Makowski, this situation can be understood a little differently, as lobbying or advocacy can also be forms of participation or consultation (G. Makowski, 2012, p. 24-25).

Unlike with a local referendum, the aim of public consultations is not to decide on issues essential to a self-governing community. What is more, they are a form of expressing the residents' opinion in gremio. Owing to them, 
members of a local or regional self-governing community can participate, as a consulting body, in the process of making decisions essential to the local government unit. In the literature of the subject, public consultations are usually characterised by their social function. According to Z. Leoński "consultations are a form by which residents' express their opinions" (Z. Leoński, 2006 , p. 104). W. Kisiel claims that public consultations mainly involve residents expressing opinions on the method of solving an issue, which is in no way binding on the authorities (W. Kisiel, 2006, p. 125). Another interesting analysis of the issue was published by Z. Niewiadomski, who thinks that "in their essence, consultations enable residents to express their opinions, expectations or to submit a request regarding the method of solving an issue which lies within the competence of a local government unit" (Z. Niewiadomski, 2011, p. 64). Interesting observations on public consultations are presented by P. Uziębło. He describes consultations as a way of expressing opinions by the residents, or some of them, on strictly defined public matters, with such opinions being basically non-binding, and the bodies making decisions on an issue not having to act on them (P. Uziębło, 2009, p. 53).

Public consultations can also be regarded with respect to their organisational function, provided that-as mentioned by R. Marchaj-such organisation combines all actions focused on achieving planned objectives (R. Marchaj, 2020, p. 66-75). He also points out that, in an administrative approach, public consultations make a bilateral and orderly process, in which a local government unit, authorised to make a decision in a matter, can present its arguments and allows those concerned to express their opinions. In a functional approach, public consultations are a form of active participation of residents of a local self-governing community in the process of preparing specific decisions implemented by the local government. Owing to such actions, the residents can exercise control over the decisions taken by the commune authorities. A similar function is performed, for example, by a local referendum, which is a form of preliminary control. Moreover, public consultations are an element of direct democracy, usually having a form of expressing residents' opinions, which are not always decisive in a matter. 


\section{Propositions OF DE LEGE FERENDA REGARDING PUBLIC CONSULTATIONS}

There is no doubt that public consultations are a tool used in implementing the democratic form of government and that they contribute significantly to the development of civil society. Using public consultations by local government units also supports the performance of their public tasks as part of developing and nurturing the process of decentralisation of public authority (M. Bożek, 2012, p. 103-107). The formal validity of judicial decisions of administrative courts, which construe the provision of Art. 5a (1) of the act on commune self-government in this manner, is obviously unquestionable. This approach eliminates by-laws which exclude any category of commune residents from participation in public consultations (K. Kozłowski, 2018, p. 39-43). A rational and real assessment of this legal provision and accompanying judicial decision shows that it does not correspond to the principles of the legal system (Judgment of the Supreme Administrative Court in Warsaw of January 14, 2014-II OSK 2988/13, LEX 1452864).

The right to participate in the social life in the commune, in the district or in the voivodship, including the right to take part in public consultations, like any other right, is not absolute. Moreover, it can often be restricted proportionately in justified cases. An effect of public consultations is to provide important guidance to the competent decision-making authorities, i.e. the commune head (mayor) and the commune council, regarding the method of handling an issue as wished for by the residents (D. Sześciło, 2012, p. 22-23). The outcome will never constitute a private act, but it will always put specific pressure in the public sphere, assuming a legally, politically and socially significant nature (Z. Leoński, 2006, p. 103). Therefore, the decision-making process associated with public consultations on a specific matter should involve residents of a local self-governing community, who are able to make conscious decisions resulting in the authorities taking specific actions. However, it is known that everyone has equal rights to participate in public life and no one can be deprived of such rights in whole or in part.

The current legal order, confirmed by consistent judicial decisions in this regard, seems to result - ad absurdum - in a situation in which opinions 
on important public matters can be expressed by minors, legally incapacitated individuals or those who are deprived of public rights under a court sentence. An analysis of this situation shows that the legal system links the inability to perform legal acts with the impossibility of using not only basic civil rights, but also excludes such individuals from participation in making public decisions.

It is important that electoral regulations impose certain restrictions regarding participation in elections and referendums (B. Banaszak, 2017, p. 342344). It has already been emphasised that such restrictions apply to minors, incapacitated individuals and those deprived of public rights or electoral rights in a way that results in their inability to take part in elections or in a referendum, either local or regional (K. Kozłowski, 2018, p. 40-42). The legal system must be lenient in broadly defining the category of "residents" who are entitled to participate in consultations. Such an approach should result in the wide participation of the commune, district and voivodship residents in the process of deciding on important matters in local self-governing communities (M. Kulesza, D. Sześciło, 2013, p. 113-128).

There may be situations when the value of public consultations will decrease and they may (or may not) turn against the values upon which they were created. The provisions of the Constitution of the Republic of Poland should not be construed as objecting to statutory rationalising the category of local government unit residents entitled to participate in public consultations. It seems that such right can be derived from art. 1-2 in reference to art. 16 (1-2) of the Constitution of the Republic of Poland given an apparent space for its limitation. This limitation arises directly from Art. 31(3) of the Constitution of the Republic of Poland, where the constitutional human rights and civil liberties can be restricted only by an act of the Sejm and only when necessary in a democratic state for its security or public order or the protection of the natural environment, human health and public morals, or the rights and liberties of other individuals. Such restrictions cannot violate the essence of liberties and rights (Art. 31 (3) of the Constitution of the Republic of Poland).

Granting apparent freedom in establishing the mode and procedures of holding public consultations in communes, districts and voivodships is 
important because it is possible to flexibly adjust the form of holding public consultations to the local specificity of a given local self-governing community. However, there are still situations in which the solutions implemented in a local community may be unsatisfactory with respect to holding public consultations in an effective way. Therefore, it becomes justified to incorporate such elements in the relevant legal regulations that would have to be referred to in a resolution on the manner and procedure of holding public consultations. These relationships should obligate the decision-making bodies of local governments to define several tasks, i.e.:

- taking up the residents' initiative, starting the public consultation process;

- $\quad$ specifying the forms in which the public consultations are to be held; establishing precise mechanisms and procedures for holding public consultations and informing about the method of holding them and their result.

\section{Conclusions}

Public consultations are one of the key instruments in implementing the values of participatory democracy at the local government level. In the political aspect, these assumptions allow for citizens' active participation in the decentralised model of public authority. The principles of public consultations laid down in the constitution and their importance stressed in international law should encourage local governments at all three levels to use this form of communication with their citizens more often. This, in turn, can ensure greater acceptability of public tasks assigned to local governments. Public consultations may also contribute to the development of civil society, based largely on shaping the right relations between the local authorities and the residents, with a guarantee of partnership, mutual trust and respect.

It seems justified that public consultations in local communities should precede each decision important for the community, not connected to an obligatory resolution or ordinance. The advisory nature is a common feature 
of all consultations procedures, regulated in local government acts. However, it does not mean that because of such mechanisms local authorities do not use the consultation outcome in carrying out many public matters. Such actions frequently provide commune, district and voivodship authorities with opinions of the community on planned official and public decisions. And this, in future, will cause local government units to more frequently use this method of obtaining information, which is often necessary to carry out matters essential to the proper functioning and development of local administration. 


\section{REFERENCES}

Banaszak, B. (2017). Prawo konstytucyjne. C.H. Beck. Warszawa. ISBN 978-83-2559491-6.

Banat, M. (2014). Konsultacje społeczne w samorządzie terytorialnym. „Samorząd terytorialny". Nr 1-2. ISSN 0867-4973.

Bożek, M. (2012). Konstytucyjne podstawy partycypacji społecznej i formy jej realizacji w samorządzie terytorialnym. „Przeglą Sejmowy”. Nr 5. ISSN: 1230-5502.

Grabowska, S. (2009). Formy demokracji bezpośredniej w wybranych państwach europejskich. Wydawnictwo Uniwersytetu Rzeszowskiego. Rzeszów. ISBN: 978-837338-440-8.

Kisiel, W. (2006). Normatywne różnicowanie struktur samorzadowych [w:] Prawo samorzadu terytorialnego $w$ Polsce. Bandarzewski K., Chmielnicki P., Kisiel W. (red.). Wydawnictwo Naukowe PWN. Warszawa. ISBN: 83-7334-538-8.

Kozłowski, K. (2018). Gminne konsultacje społeczne-analiza konstytucyjnoprawna. „Samorzad terytorialny”. Nr 1-2. ISSN 0867-4973.

Kulesza, M., Sześciło, D. (2013). Polityka administracyjna i zarządzanie publiczne. Wolters Kluwer. Warszawa. ISBN: 978-83-264-4097-7.

Leoński, Z. (2006). Samorząd terytorialny w RP. Wydawnictwo C. H. Beck. Warszawa. ISBN: 83-7483-132-4.

Marchaj, R. (2020). Samorządowe konsultacje społeczne. Propozycje de lege ferenda. „Samorzad terytorialny”. Nr 7-8. ISSN 0867-4973.

Makowski, G. (2012). Przegląd prawno-instytucjonalnych ram konsultacji społecznych na poziomie samorządu terytorialnego. [w:] Prawo a partycypacja publiczna. Bilans monitoringu 2012.. Sobiesiak-Penszko P (red.). Fundacja Instytut Spraw Publicznych. Warszawa. ISBN: 1978-83-7689-110-1.

Mączyński, M. [w:] Chmielnicki, P. (red.). (2007). Komentarz do ustawy o samorządzie gminnym. Wydawnictwo LexisNexis. Warszawa. ISBN: 978-83-7334-770-0.

Olejniczak-Szałowska, E. (1997). Konsultacje we wspólnocie samorządowej. „Samorząd Terytorialny". Nr 1-2. ISSN 0867-4973.

Sitek, B. (2016). Zasady etyczne stosowane w cyberprzestrzeni. W: B. Sitek. J. Knap. S. Sagan. Ł. Roman. Nowoczesne narzędzia informatyczne w przeciwdziałaniu zagrożeniom bezpieczeństwa. Józefów: wyd. WSGE. ISBN 9788362753789.

Sitek, M. (2017). Jakość prawa miejscowego jako warunek dobrze funkcjonującego samorządu. „Journal of Modern Science”. Nr 1. vol. 32. ISNN: 1734-2031.

Sitniewski, P. (2020). Odmowa dostępu do informacji publicznej. Przesłanki, granice, procedura. Wydawnictwo Wolters Kluwer. Warszawa. ISBN: 978-83-8223-148-9.

Sześciło, D. (2012). Uwarunkowania prawne budżetu partycypacyjnego w Polsce. „Finanse Komunalne”. Nr 12. ISSN: 1232-0307.

Uziębło, P. (2009). Demokracja partycypacyjna. Wydawnictwo Centrum Badań Społecznych. Gdańsk. ISBN: 978-83-929693-0-3. 


\section{Normative ACTS AND RULINGS}

Constitution of 2 April 1997 (Journal of Laws of 1993, no. 61, item 284, as amended). Act of 6 May 1987 on social consultations and referendum (Journal of Laws 1987, No. 14, item 83).

Act of March 8, 1990 on commune self-government (consolidated text, Journal of Laws of 2020, item 713, as amended).

Act of 5 June 1998 on poviat self-government (consolidated text, Journal of Laws of 2020, item 920).

Act of 5 June 1998 on voivodship self-government (consolidated text, Journal of Laws of 2020, item 1668).

Act of April 24, 2003 on public benefit and volunteer work (consolidated text, Journal of Laws of 2020, item 1057).

Judgment of the Constitutional Tribunal of 27 November 2000 (U 3/00, OTK 2000/8, item 293).

Judgment of the Supreme Administrative Court in Warsaw of January 14, 2014, II OSK 2988/13, LEX 1452864.

Decision of the Supreme Administrative Court of 17 December 1996 (II SA / Kr 1766/96). 